\title{
We're Not Barbie Girls: Tweens Transform a Feminine Icon
}

\author{
Louise Collins, April Lidinsky, Andrea Rusnock, and Rebecca Torstrick
}

"Reinventing Barbie" was a workshop for middle-school girls to discuss, critique, and reflect on the construction of female bodies and feminine identities in popular culture by remaking Barbie dolls. The workshop was designed to foster conversations with and among girls about what it means to be embodied as female in American culture. The girls reconstructed Barbies based on their reflections, and then they came together to discuss their dolls as expressions of their visions for transforming the feminine. The article analyzes the collaborative process of the workshop, which was grounded in women's studies scholarship and developed by an interdisciplinary group of feminist academics.

Keywords: Barbie / beauty / body image / body project / feminist workshop / intergenerational mentoring / middle-school girls / popular culture

"Barbie, you're beautiful. . . . Someday, I'm gonna be 'xactly like you. Till then I know just what I'll do: Barbie, beautiful Barbie, I'll make believe that I am you."

—Mattel jingle, Barbie television advertisement (I959)

"I think Barbie is so popular because she's so pretty and she's fun to play with. You could pretend it's you when you grow up."

-Workshop participant (2006)

(C) 2012 Feminist Formations, Vol. 24 No. I (Spring) pp. 102-126 
"There is an urgent need to teach critical thinking skills in viewing and consuming media, focusing specifically on the sexualization of women and girls."

-American Psychological Association (2007)

"[Barbie] makes people think that's what they

HAVE to look like but they don't."

—Workshop participant (2006)

What do girls think, feel, and hope when they play with Barbie? What "body projects," to borrow from feminist historian Joan Jacobs Brumberg (I997, 97-137), does Barbie invite, in terms of imitation, critique, and self-definition? What new forms of pleasurable play might emerge when feminist adults ally with girls to reflect on and reinvent dominant images of femininity in mass culture? At Indiana University South Bend our interdisciplinary group of feminist scholars-an anthropologist, an art historian, a philosopher, and a women's studies professor-designed a "Reinventing Barbie" workshop for girls to consider, and remake, Barbie dolls as a way of distilling their thoughts about popular images of female bodies and identity in American culture. We had multiple goals for this project: to move women's studies scholarship into practice in the community; to foster constructive, self-reflective conversation about bodies with local middle-school girls; and to develop a model for structuring those conversations that could be used by other teachers and community activists in their own settings. This article analyzes our collaborative process. We explain some empirical and theoretical issues motivating our concern about girls and body image, and identify Barbie as a particularly apt figure for focusing these issues, acknowledging that the doll provokes a variety of spirited responses among feminists. We sketch the campus context from which we launched our workshop, and describe the workshop format and the girls' responses. We then describe how the girls remade their Barbies, and close with reflections on the successes, limitations, and further applications of our project.

\section{Why Our Concern with Girls and Body Issues?}

As women's studies affiliated faculty, as aunts, mothers, and friends of girls, we have been struck by the intense, double messages targeting young girls in a pop culture moment that embraces "girl power"-mostly of the sexy sort-that is enabled by commodity culture. On the one hand, post-Title IX, girls are participating in sports and public life in greater numbers than ever before; on the other, as Susan Douglas (20I0) argues, there is a "price we're supposed to pay for having freedom and independence: we must reassure everyone that we're 
still girls, not at all threatening, not remotely lured in by anything resembling feminism" (218). According to The Supergirl Dilemma, a report commissioned by Girls Inc. in 2006, "[g]irls are internalizing our culture's conflicting and unrealistic expectations of girls and women. Particularly troubling is the overemphasis on physical perfection, even at very young ages. . . . 'Even today,' sums up one ninth-grade girl, 'society values beauty in girls over intelligence and insight." The study found that 84 percent of girls believe they have to be thin to be popular, an increase from the 75 percent who shared this belief in 2000. ${ }^{1}$ Sports researchers Ellen Staurowsky and colleagues (2009) characterize serious psychological and physical health risks associated with girls' negative body images: "Although boys also experience dissatisfaction with their bodies ... girls are especially vulnerable to developing and investing in a negative body image. . . Negative body image is often associated with disordered eating . . . depression ... poor self-esteem ... and even abuse of substances with appetitesuppressing qualities ... especially cigarettes" (43). There is widespread evidence of deep and damaging dissatisfaction about their appearance among girls and young women. ${ }^{2}$

At the same time, the fashion-beauty-diet industrial complex intrudes deeper into the lives of ever-younger girls, as companies seek to exploit new market niches for their products. "Kid-friendly" cosmetic products like fruitflavored lipgloss and body glitter are now targeted for sale to pre-teens and younger. National franchises market "tween idol" makeovers to 6-year-old girls that feature shimmying down a catwalk in low-cut pants and sequined spandex tops while being exhorted to "Wet your lips and smile to the camera" (Copeland 2006), and sell birthday "primping parties" for 6- to 9-year-old girls (Sweeney 2008). These products go beyond the fun of "dress-up" and stage-makeup for kids in constructing a precocious, sexualized child femininity. Even the mainstream American Psychological Association (2007) reports concern about the destructive consequences of mass media's increasing sexual objectification of young girls: "Ample evidence ... indicates that sexualization has negative effects in a variety of domains, including cognitive functioning, physical and mental health, sexuality and attitudes and belief" (2I-22).

American girls today are subjected to powerful forces that are affecting their identity development in historically unprecedented ways. Brumberg (I997) has argued that girls today make their body - its shape, clothes, hair, heterosexual attractiveness - into their central project of self-definition-the "body project." She argues that the process of maturation for girls changed over the course of the twentieth century. Whereas, in the nineteenth century, emphasis was placed on training girls' moral character, their self-control, and devotion to the community and piety in preparation for motherhood, today, becoming properly feminine is centered on the achievement of a certain kind of physical self-presentation. In her classic feminist analysis of the phenomenology of internalized oppression, philosopher Sandra Lee Bartky (I990) concurs: 
"Normative femininity is coming more and more to be centered on a woman's body — not its duties and obligations or even its capacity to bear children, but its ... presumed heterosexuality and its appearance” (80). Brumberg (1997) also notes the decline in mentoring of adolescent girls by older women in single-sex groups and comments that young girls today are increasingly left alone with their age peers to cope with a mass media saturated with messages that define females' worth in terms of their looks.

Staurowsky and colleagues (2009) note the deleterious impact on women and girls of such messages: "Popular imagery in media, literature, and advertising emphasizes a vision of female physical perfection that is unrealistically thin. ... To the extent that girls and women internalize such consistent messages .. . they are apt to make unfavorable comparisons between this idealized, unrealistic form and their own bodies" (43). Bartky (I990) argues that mass media teaches that female bodies are naturally inferior and in need of constant improvement: "Soap and water, a shave, and routine attention to hygiene may be enough for him, for her they are not. . . The media images of perfect female beauty which bombard us daily leave no doubt in the minds of most women that they fail to measure up" (7I). Girls learn to follow ever more demanding, and often costly, regimens of grooming, diet, exercise, and cosmetic surgery in pursuit of ideal feminine beauty, or even what they are taught to regard as minimal social acceptability. Appropriating Michel Foucault's (1979) language from Discipline and Punish to her feminist purposes, Bartky claims that women are subjected to disciplines of feminine corporeal normalization. Young girls internalize the habit of scrutinizing their own appearance for its acceptability to the heterosexual male gaze (72); as one girl in our workshop scrawled across a life-size silhouette of Barbie: "Too many mirrors to look in." Douglas (20I0) argues that performing proper femininity demands the micro-management of female bodies and produces a troubled subjectivity: "In addition to inhabiting a weird sort of third-person perspective on our faces and bodies-watching ourselves being watched by others-experiments have shown that this amount of self-scrutiny can be so mentally and emotionally demanding that it can sap the energy and confidence needed to focus on other things" (2I8-I9).

Such critiques of the "cruelty" of the beauty ideal may seem to ignore the satisfaction and rewards many women and girls find in "taking care of their feminine good looks," the pleasurable opportunity such activities as doll-play and dress-up provide girls to bond with one another and the agency and choices of females themselves. The dilemmas inherent in trying to view these practices as positive are well documented by Kathy Davis (1993) for cosmetic surgery and Iris Marion Young (I990) for dressing up. Clearly, neither women nor girls are unthinkingly obedient to cultural commands to wear makeup or follow mainstream fashion or diet. Many women and girls report finding activities from Barbie play to facials and cosmetic surgery enjoyable, worthwhile, and even liberatory, and feminist methodology requires us to begin by attending to 
women's and girls' accounts of their own experiences. However, as feminist philosopher Kathryn Pauly Morgan (1995) persuasively argues, using the example of elective cosmetic surgery, women's apparently free choices about beauty and self-presentation are often deeply constrained by the oppressive institutions and practices of heteropatriarchy and white supremacy. Paradoxically, what the individual woman, or girl, experiences as the exercise of self-expression and self-care may turn out to be an instance of conformity, colonization, and coercion, given the double-binds of patriarchal norms of femininity. These double-binds are multiplied for girls and women of color; despite the more diverse images of feminine beauty now displayed in some advertising media, as Tracey Owens Patton (2006) argues, the hegemonic ideal of beauty in America remains coded white.

Given these critiques of mainstream beauty norms, the challenge for feminism is to imagine and create new and more joyful ways for women and girls to live as embodied persons (Heyes 2007). Simply rejecting mainstream beauty ideals does not yet open up strategies for imagining positive, feminist alternatives, and it risks replicating the cultural double-bind whereby girls are criticized for their vanity if they struggle to conform to beauty norms, but are also criticized should they fail to do so. Further, Mary Celeste Kearney (2009) reminds adult feminists to acknowledge and respect girls' experiences and agency: "Through their involvement in youth cultures, like hip-hop and riot grrrl, girls are actively asserting themselves in the public sphere and thus reconfiguring both girlhood and girls' culture" (15), but that does not mean that adult feminists should abandon girls to cope with a powerful and toxic mainstream popular culture unaided. Revising Brumberg's (I997) idea of intergenerational mentoring, we sought to position ourselves as mentor/allies to the girls in our project.

Given the complex concerns about agency raised above, our limited resources, and the reality of our location in a socially conservative community, we decided to design a small-scale outreach project: a workshop on our campus centered on modifying Barbie dolls. Fashion doll-play is culturally approved as a gender-appropriate recreation for girls, so a workshop on this topic could be expected to have wide appeal. At the same time, fashion doll-play is triply stigmatized: as childish (thus "trivial"); as related to beauty (thus "vain" or "frivolous"); and as coded feminine (thus "Other"). ${ }^{3}$ Recuperating Barbie as a potential ally in a feminist project seemed an appropriate and playful response to widespread depreciation of girls' culture. The creative, reinventing dimension of the project would engage girls in the pleasures and risks of literally "making over" an aspect of patriarchal culture according to their own visions, thereby concretizing the girls' reflections on popular culture and femininity.

As we planned the workshop, we discussed our own personal ambivalences about Barbie's collusion with heteropatriarchal, consumerist culture, while at the same time acknowledging the remembered pleasures of childhood doll-play 
(Reid-Walsh and Mitchell 200I). In developing the workshop format, we tried to provide enough structure and eclectic raw materials to invite focused thinking about embodied femininity, but without imposing our own expectations about how the girls "should" view Barbie and reinvent or remake her.

\section{Why Pick on Barbie?}

Reinventing Barbies struck us as especially apt for our workshop goals because of the doll's specific history and identity as a body-project doll, and also because of the rich American artistic tradition, to be discussed below, of works that celebrate or critique the doll. When Barbie was introduced to the American toy market in 1959 she represented an important break from childhood dollplay as traditionally conceived. Barbie was one of the earliest "adult-figured," three-dimensional dolls to be manufactured for girls in America, and she was marketed directly to them via the novel medium of television advertising. In the I950s, Ruth Handler saw the potential for combining two long-established types of doll-play: play with baby dolls, and play with paper cutouts of fashionable adult women. The idea for this new toy came to Handler as she watched her daughter Barbara and her friends using paper dolls to imagine and act out their own possible adult lives (Lord 1994, 29-30). Thus Barbie was born: a threedimensional dress-up doll for girls, with a young woman's figure.

The Mattel Corporation was an innovator in marketing, employing experts trained in psychology to design advertising for the new medium of television to sell Barbie directly to girls. Increasingly, children would look to the mass media, rather than their local peers, for ideas about what to play with and how (Chudacoff 2007). Mattel, advised by its cadre of play research experts, showed girls how to play with this new kind of doll, while reassuring moms wary of Barbie's "mature" looks that Barbie-play would help girls grow into marriageable ladies. Subsequently, through the scripts of television advertisements and text and images on the packaging of Barbie merchandise, Mattel continues to prescribe a paradigmatic form of play for girls always mediated by consumption.

Classic Barbie-play involves sitting still, in a domestic venue, dressing the doll in various purchased outfits and grooming her hair. With her default identity as "Teen-Aged" (Mattel's original marketing term) fashion doll and defined by fashion and grooming no matter her ostensible new career or activity, Barbie is the quintessential "Body Project doll" (Jones 1999, 9I-I07). Thus Astronaut Barbie (I986) accessorizes with a spangled space suit and irrepressible smile, and Computer Engineer Barbie (20I0) complements her Bluetooth headset with a hot-pink laptop and wedges. Even in outer space or under a desk feeding cables through a wall, Barbie is always "lookin' good!" Paradigmatic Barbie-play trains girls to judge themselves and other girls in relation to a restrictive beauty ideal, and to define their identities in terms of bodily self-presentation. Such play thus fits Bartky's (I990) description of disciplines of feminine corporeal normalization. ${ }^{4}$ 
Barbie's longevity is, in part, due to Mattel's deft repackaging of the doll to capitalize on emerging trends and niche markets, while retaining the preoccupation with appearance and prettiness that remains coded as white, slim, affluent, and able-bodied. Thus, although a side effect of the "kids getting older younger" (KGOY) phenomenon is that Barbie is now marketed to younger girls via a fairy-princess fantasy genre that, as Peggy Orenstein notes in Cinderella Ate My Daughter (20II), pink-washes any class implications of real princesses; the core play remains grooming and now hyper-feminine dress-up. With Douglas (20ro), one might also read Fairytopia/Princess Barbies as an instance of the duplicitous workings of "enlightened sexism" (9-16), whose logic proceeds thus: since, for example, we can in 20I I buy Architect Barbie (despite the underrepresentation of women in the profession), feminism's work is widely and mistakenly assumed to be done ("embedded"), and there appears to be no problem about encouraging girls to embrace "girlie-girlness" (Orenstein 20I I, 6).

Another reason to pick on Barbie for our workshop is the long tradition of using the doll for artistic expression. As a body-project muse, Barbie has inspired a range of high art works, most famously Andy Warhol's I985 portrait, which is owned by Mattel. David Levinthal used the doll as the "model" in a photo shoot, complete with her own stylist, for a Polaroid series celebrating her fortieth anniversary (I998-99). Levinthal later did a less reverential photo series, Bad Barbie, in which he positioned Barbie in sexually suggestive poses (20I0). Another genre for the doll in the art world is the reinvented Barbie: professional artists have repurposed Barbie, sometimes with a vigor unappreciated by Mattel, to create unique works of art. Brett Reif, for example, battered and fried numerous dolls and from them created a sculptural work, Fried Barbis (2003). Entire exhibitions have been dedicated to remade Barbies. Altered Barbie, a group show in San Francisco that had its ninth incarnation in 20II, features myriad reinvented Barbie dolls - from Barbie torsos in a frying pan, to a chessboard upon which Barbie-headed pieces face off against Powerpuff Girl-topped opponents, to larger works that incorporate varied Barbie body parts. The young girls and their reconfigured Barbies in our workshop thus can be viewed within the artistic tradition of using the doll as a subject, a sculptural armature, or simply as found material for assembly.

We then needed to check whether Barbie is still relevant to middle-school American girls as an icon of feminine beauty, despite the popularity of Bratz dolls and other rival products. Gigi Durham (2008) notes that whenever she interviews Americans about what a "perfect girl" looks like,

I get the same answer every time I ask this question: in my college-level classes on gender and sexuality, in casual conversations with colleagues, when I talk to my friends' pre-school children. Over and over again, "Barbie" is what they come up with, despite all the years of critique, the debates, and the derision; despite the incursion of the newer, more popular dolls; despite Fat Pride and 
the butch mystique. "Perfect girls" in the new millennium, apparently, still look like Barbie. (95)

Tara Kuther and Erin McDonald (2004) concur that Barbie dolls remain "pervasive" in the experiences of young girls, and that Barbie dolls "represent [physical] perfection" for those girls $(50,44)$. Despite the plethora of girl-culture commodities on today's market, Barbie still maintains a vibrant presence in Americans' pop-cultural imagination as a plastic personification of the social contradictions of femininity. In addition to the many thriving Barbie-themed websites and collectors' events, references to Barbie recur in the mass media, from singer-songwriter P!nk's 2006 video for her song "Stupid Girls," in which a girl rejects a Barbie doll in favor of a football, to the dubbing of 2008 U.S. vice presidential candidate Sarah Palin as "Caribou Barbie." Even such satirical references testify to the widespread cultural intelligibility of Barbie. Huge numbers of Barbie dolls continue to be sold in America and overseas. According to the San Francisco Chronicle ("Barbie Brand Sales Snag \$3 Billion a Year Globally" 20I I), Mattel sells $\$ 3$ billion of Barbie-branded merchandise globally each year. In the fourth quarter of 2oI0, Barbie sales pushed quarterly profits up for Mattel by 86 percent (Anderson 20I0), while Barbie sales in the first quarter of $201 \mathrm{I}$ rose 8 percent (Chang 20II).

\section{Feminist Theorists and Barbie}

Feminist scholars are clearly still working through Barbie's cultural functions, and while Barbie may never be totally resuscitated at a feminist conference devoted to her curvaceous plastic benchmark, a solid body of analysis exists on the ways in which both children and adults play, manipulate, and imagine with Barbie. Many scholars have noted the contradictory claims of Barbie merchandising: on the one hand, Barbie seems to teach girls that they can "do anything," and on the other, the primary theme of Mattel's Barbie merchandise has been frilly clothes for an impossibly exaggerated female form. Some feminists find a grain of truth in Handler's view of Barbie as a role model who offers girls a career beyond motherhood, in contrast to baby dolls (Handler I994, 43-44; Inness I999, I77-8I; Reid-Walsh and Mitchell 200I, I75-90); others, like Anna Quindlen (I999), urge us to drive "[a] silver lamé stake through [Barbie's] heart" (I I) for marketing an unattainable ideal of physical beauty to girls in their early and vulnerable years, when their identities are being formed (a view supported by Helga Dittmar, Emma Halliwell, and Suzanne Ive's 2006 study).

Not only are Barbie's bodily dimensions unhealthy, but her looks arguably reflect and reinforce racist, heterosexist, and ableist values. Scholars of race and gender differ on the role that Barbie's originary whiteness plays in her reification of normative feminine beauty. Feminist critic Ann duCille (I994) notes that Mattel's production of "ethnic" Barbies may be an "easy and immensely 
profitable way off the hook of Eurocentrism" (52), but she ultimately argues that the marketing of "multicultural" Barbies simultaneously capitalizes on the concept of exotic difference, and practically eliminates difference through the mass-produced Barbie bodies that are essentially the same so that the clothes and accessories are interchangeable (see also Rodriguez I998; contrast Raynor 2009). As we will see below, some girls in our workshop perceived Barbie's default whiteness as central to her desirability and power.

Beyond simple pro- or con-Barbie views, one must also note the complex possibilities of agency opened up in Barbie-play, in line with feminist appropriations of Foucault and postmodern theory (Bartky I990; Bordo I989; Heyes 2007). Finally, girls' studies scholars like Catherine Driscoll (2002) remind us that interactive play with Barbie is often quite complex and multifaceted, and that, problematically, "[f]eminist critique of Barbie . . sometimes participates in the mainstream devaluation of girl culture" (98). She argues that Barbie can be seen as "an assemblage of girl-doll relations [that] puts girls into relation with a gender machine" (97). Considering Barbie as a dynamic site of interaction and intervention, as Driscoll does, places girls in a more agentic position than do some critics, who perhaps inadvertently reproduce the "moral panic" (Mitchell and Reid-Walsh 2007, 440) around adolescent female bodies that have shaped discussions of girlhood for centuries. Thus, as we began designing our interactive workshop and attendant campus events, we strove to be mindful of assumptions we might make as feminist scholars that could blinker us against the girls' rich and diverse responses to Barbie. Listening to the girls was the first step in our workshop as we tried to provide some structure, but mostly openness and opportunity for the girls to set the conversational agenda once Barbie was—quite literally_ on the table.

\section{The Campus Context}

Significantly, we held our Reinventing Barbie workshop during a year in which our campus theme was "The Mutable Body," which created a rich context of other campus events, such as courses about representations and politics of the body, art events, and a lecture series. Our project began with a campus exhibit of the work of Beverly Naidus, professor of interdisciplinary arts, media, and culture at the University of Washington Tacoma. Her exhibit, titled "One Size Does Not Fit All," displayed her mixed-media responses to poisonous popularculture narratives about the female body. Naidus also gave a lecture titled "You're Such a Complainer" on socially engaged art and offered a workshop for faculty and students on strategies of using art for social activism, which helped us shape our own Barbie workshop, described in the next section. ${ }^{5}$

Naidus's witty and thought-provoking work provided a useful backdrop for the other events of the spring, which included a well-attended "Barbie and Body Talk" featuring two scholarly presenters from our campus. The discussion with 
undergraduate students afterward wandered from fat phobia to different kinds of Barbie-play. We also held a three-day campus teach-in late in the semester titled "Barbie and Body Talk," with tables set up in the main hallway of our busiest classroom building with information about Barbie and recent news articles about her. We had large photos of nude Barbie and Ken on display on the walls, with paper and markers for passers by to record their thoughts and share stories with us about playing with, hating, or loving them.

Some individuals expressed relief that we were talking about "those awful things"; others told us to "Get over it—it's just a doll." We heard a lot of stories from adults about Barbie in those days, and a few about Ken and G.I. Joe also. Many of the same themes that concern feminist scholars came up in those conversations - for example, a wish for more darker-skinned dolls; for fuller-figured dolls; for dolls that would not make girls feel bad. Our table display included some of the reinvented Barbies the children had produced, and students pored over them, often amazed by the imagination, humor, and vision of these girls who used art for activism in exactly the same way as artists like Naidus do. While the Reinventing Barbie workshop we designed was for middle-school girls, it was striking how many adults came by our table to express strong feelings about children's toys - either from their own childhood memories or from their experiences as parents and grandparents. Some passersby at our table talk took issue with criticisms of Barbie (compare college students' reactions to classroom discussions about Barbie in Amy Damico and Sara Quay's "Stories of Boy Scouts, Barbie Dolls, and Prom Dresses” [2006]); like Melissa Hook (I999), they recounted happy hours of bonding with their grandmothers in Barbie-play and argued that Barbie was just wonderful, innocent fun to bond over (I69-74).

Because we all have personal experience with popular culture, we found that Barbie is, indeed, a rich vein to tap into when it comes to inviting both our students and the wider community of parents and children into thoughtful conversations regarding what we really think about women and women's bodies - about women and power and resistance-and about what girls today think about the present and their futures. Through the workshop, as will be explained below, we moved women's studies' power of praxis into the community, with some very interesting results.

\section{The Workshop Process}

In developing our workshop, we worked with an art educator from our local art museum and an art-education faculty member to refine the design and ensure that it was age-appropriate for middle-school girls (ages Io-I4). We offered three different sessions of the workshop: one in March and two in May. For our March session-a pretest to work through any bugs - we recruited girls from among our own families and friends. We sent e-mails to women's studies majors and minors and all Indiana University South Bend students and contacted local 
community groups like the American Association of University Women and the Girl Scouts to recruit participants for the two May sessions. Overall, 28 girls (ages 8-13) participated, with almost half being ro years old and in grade 5. The groups were also predominantly white and working- to middle-class, reflective of the students, staff, and faculty of our campus community, and also of the wider community, although there were four African American girls at one of the May workshop sessions.

We held the workshop in an art studio on campus, which had good lighting, lots of large workbenches covered with newspapers for the hands-on activities, a table and whiteboard for group discussion and notes, and a big sink for clean-up afterwards. The workshop comprised a sixty-minute series of structured group activities, followed by an hour reserved for the girls to work on recreating their dolls. The basic workshop format was as follows: introductions and snacks; "lifesize Barbie" group art exercise; group discussion on "prettiness," prompted by a five-minute film clip; circulation of sample reinvented dolls and discussion on using art for social activism; hands-on remaking of dolls; and presentation of the remade dolls to the group. We divided responsibilities for facilitating each segment among the four of us. In compliance with our institutional review board-approved protocol, one person recorded what the girls said during discussions without noting which girl said what. We had secured prior parental/ guardian permission to photograph the girls in the workshop with their dolls to use in developing a curriculum guide for teachers.

After introductions, we started the workshop by having each girl describe how she played with Barbie. At our pilot session, we asked the girls what they liked or disliked about Barbie, but we discontinued this in the next two sessions, because once some girls started recounting their dislikes the group stopped mentioning any positives about Barbie. It also seemed as if some younger girls were censoring their responses to conform to the older girls' more negative views. An age difference in attitude would parallel Kuther and McDonald's (2004) finding that "during late childhood and early adolescence [ages IO-I3], imaginative play with Barbie dolls became less appealing" (50).

When asked what they did with Barbie, the girls' answers varied widely, picking up on Barbie's "diverse and oppositional messages" (Reid-Walsh and Mitchell 200I, I76). Some girls followed Mattel's classic play-script: "Mine used to be a model, I had lots of clothes for "My Scene Barbie." They used Barbie to imagine adult lives; for example, by giving her a "whole life and a career," having her model, pick kids up from school, go to work, and perform, and playing "weddings," "real life," and "being famous." Such responses appear to support Handler's (I994) defense of Barbie, referring to career aspirations and competitiveness: "I used to act like Barbies were famous, like singers. They would dance, have a talent show." Some girls found scripts in Barbie-play to practice professional personas that are richer and more diverse than their actual communities (Reid-Walsh and Mitchell 200I, I82). 
However, the girls as a group were clearly not simply passively assimilating the mainstream requirement that girls should "play nicely." Several reported ingenious ways of destroying Barbie: Barbie would "bungee jump and die"; or she would be "thrown off a top bunk," "dissected," or "jumped on"; or she would have "her head torn off to use as Halloween decorations." Others coyly noted the damage they had secretly inflicted on Barbie, biting off her feet or discovering that "plastic hair burns easily." Kuther and McDonald (2004) also note that "[a] surprisingly common form of Barbie-related play reported [by the twenty sixth-grade girls, ages Io-I3, participating in a study] was torture play," such as pulling off the doll's head, most of which "occurred in older childhood and in the presence of boys" (42); they also distinguish a play style they dub "anger play," in which girls redirected anger from (real) people toward their dolls (43). Girls in our workshop also reported that "you can destroy a doll rather than hurt someone" and "when mad, you can toss a doll," but they did not display any anger-play.

Follow-up questions asked what the girls thought about Barbie and whether and why she is so popular. Some girls had positive things to say about Barbie (for example, she's "pretty," "a leader," "popular"), noting that the doll might appeal to young girls as a way to think about being older: "Little kids want to be older than they are. It's interesting to have a grown-up body and to act out things you'll do when you are older"; "You look up to older kids and want to be like them"; and "You see them on commercials, having different jobs, kids can think about the jobs they want to do." The last comment recalls Kay Hymowitz's (200I) bleak analysis of Barbie-play as the genesis of a limiting form of fantasy play, mainly inviting children into the commodity-rich world of the consumerist teenager (I6). We also hear in the girls' anticipation of adult female empowerment Andi Ziesler's (2008) point that our culture has comfortably co-opted the language of empowerment into the power to purchase more "stuff" marketed especially to girls and women (IO3) (see also Goldman, Heath, and Smith [I99I] on I980s "commodity feminism"). As Orenstein (20II) puts it, "[l]ong before Elle Woods or Carrie Bradshaw, Barbie was the first 'I am woman, see me shop' feminist, with all the inconsistencies that implied" (46).

Consistent with DuCille's (I994) analysis, all the girls in our workshop took it for granted that Barbie "really" is Caucasian, even though Mattel has marketed black dolls in the Barbie line for over forty years. ${ }^{6}$ This assumption was evident as one girl linked "perfection" and "blondness" in her description of Barbie: "Perfect image, the tall blond person. She's what people want to be. The perfect image of what people want." Another girl noted that "Barbie is always the leader and others are behind her," and attributed her dominance to her racialized physical traits: "[She] has blue eyes and blond hair so she is the leader" (emphasis added). Another girl concurred: "It's kind of weird. Hispanic, Chinese, Black, or Mexican dolls are behind her and she's in front.” Thus, girls in our workshop gave support to DuCille's critiques of Barbie in terms of racial 
hierarchies and to Owens Patton's (2006) description of white beauty norms as culturally hegemonic.

The girls offered a great many negative comments about what was wrong with Barbie. Her "perfectness" came up over and over again as problematic. The sixth-grade girls surveyed by Kuther and McDonald (2004) concurred: "The girls viewed Barbie as the image of perfection, and perhaps too perfect, yet she defines physical beauty" (43). An older girl in our workshop said that Barbie had "no true character, no true depth," because she's just "perfection, which doesn't exist," and another protested that Barbie was a "sex object" and her clothes were "too revealing." Several complained that other girls might feel that they should be perfect like Barbie. They all complained about her unrealistic figure (for example, "she's too skinny") and yet, when shown a "pleasingly plump" Barbie (remade to rounder proportions), the girls all agreed that people would not like her and that "people would not buy a fat Barbie." One said: "People in these times of life think you have to be skinny, pretty, be the same as others, that you need Botox." Girls often spoke of what "people" think or what "kids" would infer from Barbie, rather than using the first person. This distancing trope recurred in discussion and might suggest that the girls were already developing a resistant reading of popular culture, or that it might reflect some girls' reluctance in our workshop context to admit the appeal of mainstream ideas about prettiness.

We then gave the girls markers to draw and write on a silhouette of a human figure - a life-size Barbie — to remake her. One girl noted: "You could pretend it's you when you grow up." Even here, the predominant theme the girls continued was a litany of complaints about the doll. They wrote that she was "too skinny," "too inflexible," or "so flexible she [fell] over," had "tiny feet" and "long legs," was "unrealistic," and wore "too much makeup." While this might suggest that the girls were expressing a healthier/more generous ideal of beauty, there is an echo of the familiar reduction of women to a list of "figure flaws." One group developed a "new" Barbie, wearing a tank top and jeans with psychedelic patches and sporting tattoos and medium-length straight black hair. This might be seen as step toward reworking Barbie on these girls' own terms.

We next showed the girls a five-minute clip from Susan Stern's film Barbie Nation (1998) in which two 5-year-old white girls are shown playing with Barbie dolls and talking about prettiness. We ended the clip where one girl asserts that "[g]irls need to be a little bit pretty to have people like them," and then we asked the workshop participants for comments. The clip was used to de-center discussion from the adult facilitators toward a conversation among girls. At one session, the group agreed that girls today must be physically "flexible" to be seen as pretty, highlighting how the athletic-looking girl (and, in particular, the gymnastic girl) has become a new beauty standard. At every session, stories surfaced about how one girl or another in the group was told or teased, often by a boy, that they were not pretty as a way of bullying them. 
In the opening chapter of Full Frontal Feminism (2007), Jessica Valenti addresses the policing function of "the ugly stick," as she acknowledges the power that these easy playground insults can hold long after they are verbalized (9). The girls also said that they had female peers in school who were teased about their looks, and/or who dieted to excess or obsessed over their appearance. Some girls also mentioned worries about their own appearances; gesturing to her forehead, one girl said: "Bullies at school say, 'You ugly.' They talk about my scar." When an older girl started off by saying she "is not pretty but ...," the other girls rushed in to assure her that she was beautiful. The radical import of the rest of her statement-"I'm not pretty, but I have friends"-got lost in the group's concern to assuage what they (mistakenly) perceived as her self-depreciating remark. Indeed, even some of us adult facilitators joined in, automatically; even for adults, Valenti argues that "[u]gly is powerful. Nothing has quite the same sting" (I97). This incident nicely shows how hard it is to uncouple ideas about female well-being and identity from the question of looks.

Some girls identified a double-bind around prettiness; although girls have to be pretty to be popular, even if you attain prettiness, you may not gain popularity or respect. In one workshop, three classmates recalled a peer from second grade: "A girl named Bobbi, everyone was her friend because she was really pretty but she wasn't that smart," and "when Bobbi turned her back" people said "mean things about her." Writing on the life-size Barbie suggested a related ambivalence: "Perfect"; "Too perfect"; "Perfect = Bad"; and "So pretty she's ugly."

The girls' transformation of our stock of secondhand Barbie dolls was the critical element in this project. After engaging in somewhat abstract discussion about body image and social pressures on girls, we wanted to help them mobilize those ideas in remaking a small part of their world. Having inventoried their likes and dislikes about Barbie, we wanted the girls to be empowered to imagine her differently and to remake her according to their own visions. To help bridge the gap between abstract discussion and practical transformation, we passed two transformed Barbie dolls around the group: the "Literary Barbie" had words and Scrabble letters pasted all over her body; and the "Toxic Barbie" was Mattel's "Pretty in Pink" model Barbie, now painted a vibrant green and with ghastly spots and matted hair. Both these dolls looked strikingly different from the regular Barbies, and we hoped this would disrupt assumptions about how one "ought to" dress up Barbie, derived from Mattel-prescribed play scripts. We asked the girls what they felt about these dolls, as they handled them, and what their makers might have had in mind. One girl commented that the Toxic Barbie "reminded her of a frog," and another that the Literary Barbie looked like "an expressing self"; a third commented that "she's a creative person using words and music." This exercise was to encourage the girls to be cognizant of what they were doing in transforming their Barbie dolls and to actively engage their critical thinking skills as they worked with their hands. 
We asked the girls what ideas or feelings they might want to express with their remade Barbie dolls, which worked better with some groups than others. In all the groups, we discouraged the girls from trying to second-guess what the facilitators "wanted them to do." It was tricky nudging the girls to think critically and creatively about Barbie, especially on topics of feminist concern, without directing them toward a restrictive view about what girls ought to think about Barbie or (especially the younger girls) making them feel ashamed for enjoying Barbie-play.

The girls (with guidance from the adult mentors) discussed themes ranging from a macro-level, such as world issues, to a micro-level, such as personal lives, in order to generate ideas for transforming Barbie dolls. These conversations, as a matter of course, had some bearing on the types of transformations constructed for Barbie. In the first, "pilot" group, the discussion focused on world issues, from globalization to climate change to poverty. The girls may have had an independent interest in these large topics, especially as three of them had recently traveled overseas, or the topics may have reflected over-directive "priming" by the facilitators. As it turned out, few of the girls were able to make the leap from abstract discussion of these global topics to concretely remaking the dolls with these ideas in mind. The few who did evidence a link between the discussion and the finished product were, with one exception, the children of professors, who might have had more practice in critiquing pop-cultural artifacts.

Bodies and beauty were the topics of the second group, and while these issues elicited much discussion, the majority of transformations from this group concerned the issue of "prettiness" rather than body concerns. A focus on the personal was the tactic taken for the discussion with the final group, where we used prompt questions like: "What do you like about yourself?"; "What do you like about your friends?"; and so on. Taking the personal as a theme yielded the most fruitful discussions and smoothest transition to remaking; the idea of reimagining Barbie in terms of what makes someone a good friend worked as a bridge. Establishing a dialogue based on the positive was clearly the better approach for this age group.

Immediately after the discussions, the girls chose their dolls from the supply of new and used Barbies, and then selected various materials with which to transform their dolls. The girls had a preference for the longer-haired Barbie dolls; a favorite transformation activity was to cut the doll's hair, and then to put various items in the new, short hair. Our supply of Barbies included dolls with a variety of skin tones. All the girls of color in the workshop picked dark-complexioned dolls to work with, and not all the white girls picked white dolls. We distributed the raw materials for remaking the dolls across several worktables so that each girl would be encouraged to chat with different people as she searched around for materials to realize her ideas. As a safety precaution, one of us staffed the hot glue gun table at all times; the other three of us rotated 
around the room, assisting and encouraging where needed as the girls worked. We spent very little money on materials, since we wanted to design an activity that any teacher could replicate. The Barbie dolls were purchased secondhand from thrift shops for around two dollars apiece.

The materials were manufactured and organic items, dainty and coarse, both newly purchased and donated, and offered the girls a vast array of choices in a rainbow of colors. Materials included fabric, beads, glitter, paint, nail polish, buttons, macaroni, natural items (pine cones, acorn caps, lentils, sticks, burrs, flowers) and found objects (screws, washers, paper clips, bubble wrap, packing peanuts, bottle caps), as well as words and phrases cut out from printed matter. We provided a wide variety of materials so that the girls would not be constrained in terms of their creations. Of course, the available objects affected the transformations, but there was enough variety to allow the girls' imaginations to soar. The girls seemed to favor fabric - the item most often used to make clothes for the dolls. They also used lots of natural objects, which we had collected in advance. While there was a plethora of luminous beads, the girls did not take to these, perhaps because they seemed too difficult to work with. Likewise, the printed material was mostly ignored except by a few girls, who used the bits of words to advance the themes of their reconfigured Barbie dolls. Some girls enjoyed ranging around the room, foraging for materials; others preferred a sedentary style, assembling materials first and then settling down to work in one place. Several of the girls were mesmerized by the option of painting their dolls with nail polish and worked in a very meticulous and focused manner. Rather than painting Barbie's nails, the polish was mostly used to paint stripes and splashes on her body, and a few girls were fascinated by putting polish in Barbie's hair. This was an interesting repurposing of one medium of adult femininity. The girls had been instructed to come to the workshop in old clothes, and the only practical issue we faced was waiting for the polish to dry sufficiently to take the doll home.

The majority of Barbie dolls underwent further revisions after the transformation process had begun. The girls seemed to have preconceived notions of the transformed appearance of Barbie, but, upon encountering the materials, they were moved to change direction. In some cases, the girls changed the entire nature of their enterprise after selecting their materials and beginning the project, while in other cases slight alterations occurred. The modifications were no doubt due to several factors. The girls may not have had access to the materials they had envisioned in their minds, or what the girls initially tried to accomplish did not work as intended so they had to switch tactics. In some cases, they needed encouragement to persevere through such challenges; at other times, the girls seemed to be slightly influenced by their peers either through imitation or inspiration. We observed several moments of cooperation and mutual encouragement among the girls, which contributed to the happy atmosphere of the workshop. 
Once the alteration process was complete, each girl was given an index card to write on. Their first task was to create a name for their new doll. These names, for the most part, reflected the girls' new intentions for the dolls. The girls' next task was to write an explanation of the purpose of their new Barbie and/or the reason for having created their new doll. The girls then took center stage as they displayed their new-fangled Barbies for the entire group while reading what was written on the cards. Everyone listened carefully to their peers' explanations, some of whom displayed confidence in their dolls and explanations, while others were a bit more shy and took some prodding in order to do their oral presentations. The environment, on the whole, was an encouraging one for the girls, with lots of applause and admiration expressed for each girl's vision.

\section{How the Girls Reinvented Barbie}

The complete list of doll titles, given in the appendix at the end of this article, makes it clear that the girls came up with a wide variety of ideas. However, several themes recurred throughout the sessions, which can be categorized as: world issues, feminist issues, shock values, and personal interests. World issues Barbies included: "Poor Person Picking Crops Barbie"; "Mother Earth Barbie"; "Lady India"; and "Save the World Barbie." These dolls concentrated on issues of nonwhite Otherness and ecology and were adorned with various types of fabrics both in print and texture and extraneous items from lentils to text to further buttress the underlying ideas of the transformations. For example, "Mother Earth Barbie" was transformed in order to make the point that humans should be concerned about saving the earth, and that the earth cannot really be owned. To make this point with her Barbie, the young artist used blue felt for a dress that fit the doll like a globe and cutouts of green felt for the seven continents, no easy feat. The girl then attached some printed text to the dress indicating the importance of the earth and what is special about it. She wrote on her card that the doll had "nothing to do with Barbie herself [but] how the earth is beautiful."

Dolls inspired by feminist issues included: "China Girl Baby"; "Dumpster Diver Barbie"; and "Feral Barbie." These were often accompanied by discussion of how women are treated in various societies and how they can be different through their actions. "China Girl Baby" had on a rich red-silk fabric with an Asiatic pattern and was used to symbolize murdered female babies; the creator of this work stated that "she is for the little girls that are killed in China or [are] aborted because they're girls." "Feral Barbie" was one of the few dolls to be remade largely with items from nature, including twigs in her hair and leaves on her dress; she carried a stick as a staff and "lives in the forest and worships her earth goddess," indicating a knowledge on this girl's part of gender issues relating to religion. 
Transformed dolls that related a shock value were either to highlight perceived social issues or personal demons as it were, including "Gothic Barbie" and "Nun Barbie." Clearly giving a nod to goth culture, "Gothic Barbie" was dressed entirely in black, with black bits of makeup, and was created, in the words of the girl, "to annoy her mother." While "Nun Barbie" looked like a nun dressed in a habit of light blue fabric with white accents, although oddly she had high black boots, the shock came when reading the card-not even from the girl's oral presentation - that accompanied the doll. The doll was not a reflection of spirituality, but an unexpected satire on religious fervor, as the girl transformed Barbie into "a total religious freak [who] prays 89,000 [times] a day."

Dolls that related to personal issues indicated the interests of the girls transforming the Barbies and included: "Craft Barbie"; "I Love to Read Barbie"; and "Phantom of the Opera Barbie." These dolls included elements that indicated the particular interests of their respective artists, with bits of text, beads, and ribbon all inventively applied to the underlying costumes. "Craft Barbie," which had ribbon, beads, and a pink garment, was created to send a message to "tell her friends that crafts are fun, non-boring, and are filled with excitement." The craft elements of creating a transformed Barbie appealed to this young girl, and she was hoping to communicate that with her doll.

There was a dichotomy between the discussion many of the girls had conducted in all of the groups in dealing with issues of prettiness and the way they actually changed their dolls, as many still seemed to be concerned with making their dolls attractive. A few dolls were created that related directly to the issue of looks, in particular "Real World Person Barbie" and "Who Cares about My Looks Barbie." These dolls addressed the idea that looks alone do not, nor should, matter. "Real World Person Barbie" had her skin tone altered to a darker hue, as the young girl noted that the majority of world citizens are not white and, more importantly for this issue, that people "aren't just judged by their looks." Yet two of the three groups noted in earlier discussion that people are judged by their looks and not just by their peers, but also by adults.

Two trends appeared over the course of the remaking of the Barbies, often correlated with the girls' ages. The younger ones tended to "dress" their dolls in a variation of Mattel's normative Barbie-play, while they expressed their critical and creative ideas more in the context of oral discussion than on the visual level of their remakings. The majority of older girls appeared more actively engaged in actually transforming the dolls, in a manner supported by their discussions of them. These girls treated Barbie more as the personification of an idea and her new appearance as a matter of costume rather than fashion. On the whole, the transformed Barbie dolls yielded a wide variety of new and different dolls exhibiting an array of issues and concerns and indicating that the majority of girls did attempt, even if on a very basic level, to create a new and unique Barbie. 


\section{Conclusion}

Our Reinventing Barbie workshop succeeded in several important respects. The hands-on project of remaking Barbie, that icon of American beauty, provided a useful catalyst for intergenerational conversations among women and girls on some difficult and urgent questions centered on body image. The closing event of our workshop, in which each girl named and explained her remade doll to the group, was a joyful affirmation of the girls' creativity and diverse visions of embodied femininity.

The jury may be out on whether our workshop additionally provided critical and creative tools that the girls could use to foster conversations with peers, family members, and other adults on the topic of bodies and appearance in a culture so often toxic to girls' self-worth. The exclamations of interest when the girls were dropped off and picked up from the workshop seemed to suggest that conversations would continue long after the rides home were over. We hope so. Certainly, our own discussions, from this project's inception to the writing of this article, have been rich and various, drawing on both raw childhood memories and disciplinary perspectives, and enfolding the experiences and insights of the children in our lives.

There were two additional outcomes to this project, both inspired by our interactions with the girls and our own desire to continue our mentor/ally work. In June of that same year, two of us were approached by a local school for advice on developing a gender-awareness program for seventh- and eighth-grade girls. We seized on the opportunity to take our experiences working with girls through the Barbie workshop in new directions and ended up teaching next to the school's teachers over the course of the following school year, while we co-developed a curriculum focused on the issues girls (and boys) in this age group told us they have to deal with: body image, friendships, cliques, bullying, and making sound life choices. The following year, the school added fifth and sixth graders and one of us continued to work with teachers. When they expanded it to the entire school in the year after that, our involvement was no longer necessary.

The Barbie workshop participants' energetic and inventive insights about Barbie as a "gender machine" inspired one of us to revise a course she teaches on "American Girls and Popular Culture." The workshop helped sharpen her sense of girls as savvy agents in the often treacherous world of popular culture, and so she revisited the literature she taught in the class, shifting from the emphasis on literature featuring adult feminists "saving" girls from pop culture (for example, Durham 2008; Lamb and Mikel Brown 2007; Levin and Kilbourne 2008) to texts featuring girl-centered invention and intervention in popular culture (notably, Kearney 2006). What further hopes do we have for the legacy of this project? We have a template to offer others that is inexpensive, simple, and fun and could be adapted to on- or off-campus settings. Despite the lack 
of representational diversity among us as facilitators and our location in a socially conservative community, we were still able to invite rich reflection and discussion among a range of middle-school girls. This project could certainly become a productive template for longitudinal studies as well. This workshop, given its limitations, demonstrated that despite the narrowness of "acceptable" cultural standards of female worth, many girls, in fact, have some skills not only to critique those standards, but also to invent fresh and complex ways to model alternative selves. Girls have plenty to teach women about culture's more recent iterations of standards of femininity and the wide range of playful ways to speak back. At the same time, as adult scholars, we have access to many "activities and social institutions that might expand [girls'] power and improve their lives" (Kearney 2009, 22) from which minors are barred, including access to the conceptual resources and critical perspectives offered by feminist theorizing in many disciplines - to say nothing of hot glue guns and studio space. We would do well, then, to see feminist intergenerational mentoring as a two-way street.

\section{Acknowledgments}

Thanks to Sydney Borntrager, Marsha Heck, Jim Hurst, and Betsy Lucal, all of Indiana University South Bend, and to Jessi Lentych of the South Bend Museum of Art for their various contributions. Susan Jenkins, Maria Buszek, and Claudia Sbrissa offered suggestions on "high art" Barbies. Indiana University South Bend granted Louise Collins sabbatical support, which enabled the drafting of this article. Thanks are also due to the reviewers and editorial team at Feminist Formations.

\section{Appendix: Titles of Remade Barbies}

"Ancient Queen Barbie"; "Athletic Barbie"; "Barbie Barbie”; "China Girl Barbie”; "Craft Barbie"; "Dumpster Diver Barbie"; "Feral Barbie"; "Gothic Barbie"; "I Love to Read Barbie"; "Lady India Barbie"; "Mermaid Mureal [sic] Barbie"; "Mother Earth Barbie"; "Nature Barbie"; "Nun Barbie"; "Perfect but Not Too Perfect Barbie"; "Phantom of the Opera Barbie"; "Poor Person Picking Crops Barbie"; "Purple Barbie"; "Real World Person Barbie"; "Recycle Barbie"; "Save the Animals Barbie"; "Save the World Barbie"; "Sixties Barbie"; "Veterinarian Barbie"; "Who Cares About My Looks Barbie"

Louise Collins is an associate professor of philosophy and an affiliate of the Women's and Gender Studies program at Indiana University South Bend. Her research interests center on feminist ethics and social philosophy. She can be reached at loucolli@ iusb.edu. 
April Lidinsky is an associate professor of women's and gender studies at Indiana University South Bend. She teaches and publishes on the topics of women's autobiography, feminist theory, popular culture, girls' studies, writing pedagogy, and creative nonfiction. She can be reached at alidinsk@iusb.edu.

Andrea Rusnock is an associate professor of art history at Indiana University South Bend. Her research interests include Russian and Soviet art, textile art, and women and the visual arts. Her recent publications include Socialist Realist Painting During the Stalinist Era (I934-I94I): The High Art of Mass Art (2010) and the chapter "The Art of Collectivization: The I939 All-Union Agricultural Exhibition" in Totalitarian Art and Modernity (2010). She can be reached at krusnock@iusb.edu.

Rebecca Torstrick is professor of anthropology at Indiana University South Bend. Her research explores identity_-gendered, ethnic, racial_-and violence and conflict in Israel. She has written and co-written two books on culture and customs in Israel and in the Arab Gulf States for a general readership. A former director of the women's studies program at Indiana University South Bend, she has taught courses on women in developing countries, women and power, motherhood, qualitative research methods, and global perspectives on women. She can be reached at rtorstri@iusb.edu.

\section{Notes}

1. Report commissioned by Girls Inc., conducted by Harris Interactive among 2065 students (including 1059 girls and 1006 boys) in grades $3^{-12}$ and 1005 adults (ages 18 and over) within the United States, March 2006.

2. Many sources give evidence of girls' unhappiness regarding body image, shape, and weight. For example, according to the Centers for Disease Control and Prevention's 2009 Youth Risk Behavior Survey, youths in Indiana are liable to a range of unhealthy dietary behaviors, and girls are more at risk than boys. During the thirty days before the survey nearly half of Hoosier girls surveyed were on a diet in 2009, 17.5 percent went without eating for twenty-four hours or more to lose weight or to avoid weight gain, and 7.6 percent vomited or took laxatives for similar reasons (compared to about 30 percent of boys dieting, with boys fasting, vomiting, or using laxatives at about half the rate of girls). According to S. Bryn Austin and colleagues (2008), of American high school students sampled in 2000, "[o]verall, 25 percent of girls ... reported disordered eating and weight control symptoms severe enough to warrant clinical evaluation ... few reported that they had ever received treatment." According to statistics from the American Society for Aesthetic Plastic Surgery (20II), in 2010, 8,65I cosmetic breastsurgical procedures (reductions, augmentations, lifts) were carried out on females ages I9 and under; 47.4 percent of the 4,I53 breast augmentations were recorded as "purely cosmetic." While respecting the diversity of patients' circumstances and conditions, these numbers should give us pause. 
3. It should also be noted that boys who seek to play with dolls rather than militaristic/super-heroic "action figures" or who wish to dress up as fairy princesses rather than bloodthirsty buccaneers are also penalized under mainstream, heteropatriarchal rules.

4. For a Bartky-inspired analysis of paradigmatic Barbie-play in the original Mattel television advertisement and as it continues on the BarbieGirls website, see Louise Collins (201 I).

5. In an overview of her activist art pedagogy, Beverly Naidus (2007) suggests having college students make feminist action figures and holding a "reconfiguring Barbie party" (I5I), crediting the latter idea to Susan Cahan and Zoya Kocur's Contemporary Art and Multicultural Art Education (I996). Naidus's article had not yet been published at the time of our workshop, so we were not aware of this source.

6. In 1967 , Mattel launched a black version of Barbie's friend Francie; from 1968-85 it offered a completely new black doll, Christie (see Handler 1994, 95); and in I980, a black Barbie and a Hispanic Barbie.

\section{References}

Altered Barbie. n.d. Accessed 6 June 20I $1 .<$ http://alteredbarbie.com/>.

American Psychological Association. 2007. Report of the APA Task Force on the Sexualization of Girls. Washington, DC: APA. Accessed 3 June 20I I. <http://www.apa .org/pi/women/programs/girls/report.aspx>.

American Society for Aesthetic Plastic Surgery. 20I I. Cosmetic Surgery National Data Bank Statistics, 2010, table, p. Iо, "2010 Age Distribution for Cosmetic Procedures." Accessed 3 June 20I I. <http://www.surgery.org/sites/default/files/Stats2oro_I.pdf>.

Anderson, Mae. 20I0. "Barbie Got Her Game Back; Mattel Profit Leaps." 2oro. San Francisco Chronicle, 30 January. Accessed 28 May 20II. <http://articles.sfgate .com/2010-0I-30/business/I784I262_I_barbie-sales-increase-bmo-capital-markets>.

Austin, S. Bryn, Najat J. Ziyadeh, Sara Forman, Lisa A. Prokop, Anne Keliher, and Douglas Jacobs. 2008. "Screening High School Students for Eating Disorders: Results of a National Initiative." Preventing Chronic Disease 5(4). Accessed 3 June 20II. <http://www.cdc.gov/pcd/issues/2008/oct/o7_or64.htm>.

"Barbie Brand Sales Snag \$3 Billion a Year Globally." 20ı. San Francisco Chronicle, 8 March. Accessed 28 May 20II. <http://articles.sfgate.com/20II-03-08/business/ 28670768_i_ipad-barbie-dolls>.

Bartky, Sandra Lee. 1990. "Foucault, Femininity, and the Modernization of Patriarchal Power." In Bartky, Femininity and Domination: Studies in the Phenomenology of Oppression, 63-82. New York: Routledge.

Bordo, Susan. 1989. "The Body and the Reproduction of Femininity: A Feminist Appropriation of Foucault." In Gender/Body/Knowledge: Feminist Reconstructions of Being and Knowing, ed. Alison M. Jaggar and Susan R. Bordo, 13-33. New Brunswick, NJ: Rutgers University Press.

Brumberg, Joan Jacobs. 1997. The Body Project: An Intimate History of American Girls. New York: Random House.

Cahan, Susan, and Zoya Kocur. 1996. Contemporary Art and Multicultural Art Education. New York: New Museum of Contemporary Art. 
Centers for Disease Control and Prevention. 2009. 2009 Youth Risk Behavior Survey. Accessed 4 June 201 I. $<$ http://apps.nccd.cdc.gov/youthonline/App/Results.aspx?TT= $A \& O U T=0 \& S I D=H S \& Q I D=Q Q \& L I D=I N \& Y I D=2009 \& L_{I D}=\& Y I_{2}=\& C O L=$ $S \& R O W_{I}=\& R O W_{2}=\& H T={ }_{5} \& L C T=\& F S=\& F R={ }_{I} \& F G={ }_{I} \& F S L=\& F R L=\& F G L=$ $\& P V=\& T S T=T$ rue $\& \mathrm{C}_{1}=7 \& \mathrm{C}_{2}=8 \& \mathrm{QP}=\mathrm{G} \& \mathrm{DP}=\mathrm{I} \& V A=\mathrm{CI} \& \mathrm{CS}=\mathrm{Y} \& S Y I D=\& E Y$ $\mathrm{ID}=\& S \mathrm{~S}=\mathrm{DEFAULT} \& \mathrm{SO}=\mathrm{ASC}>$.

Chang, Andrea. 20I r. "Barbie Looks Good, but Mattel's First-quarter Profit Is Down." 20I I. Los Angeles Times, I6 April. Accessed 28 May 20ı I. <http://articles.latimes .com/201 I/apr/16/business/la-fi-o4I6-mattel-earnings-201 10416>.

Chudacoff, Howard P. 2007. Children at Play: An American History. New York: New York University Press.

Collins, Louise. 20Ir. "Fashion Dolls and Feminism: How Do You Solve a Problem like Barbie?" In Fashion-Philosophy for Everyone: Thinking with Style, ed. Jessica Wolfendale and Jeannette Kennett, I5I-65. New York: Blackwell Publishing.

Copeland, Libby. 2006. "Glamour Babes: At Glittery and Glossy Club Libby Lu, Little Girls Play Dress-up.” 2006. Washington Post, 25 March: COr.

Damico, Amy M., and Sara E. Quay. 2006. "Stories of Boy Scouts, Barbie Dolls, and Prom Dresses: Challenging College Students to Explore the Popular Culture of Their Childhood." Teachers College Record Io8(4): 604-20.

Davis, Kathy. 1993. "Cultural Dopes and She-Devils: Cosmetic Surgery as Ideological Dilemma." In Negotiating at the Margins: The Gendered Discourses of Power and Resistance, ed. Sue Fisher and Kathy Davis, 23-45. New Brunswick, NJ: Rutgers University Press.

Dittmar, Helga, Emma Halliwell, and Suzanne Ive. 2006. "Does Barbie Make Girls Want to Be Thin? The Effect of Experimental Exposure to Images of Dolls on the Body Image of 5- to 8-Year-Old Girls." Developmental Psychology 42(2): 283-92.

Douglas, Susan J. 2010. Enlightened Sexism: The Seductive Message That Feminism's Work Is Done. New York: Times Books/Henry Holt.

Driscoll, Catherine. 2002. Girls: Feminine Adolescence in Popular Culture and Cultural Theory. New York: Columbia University Press.

duCille, Ann. 1994. "Dyes and Dolls: Multicultural Barbie and the Merchandising of Difference." Differences 6(I): 47-68.

Durham, Gigi M. 2008. The Lolita Effect: The Media Sexualization of Young Girls and What We Can Do About It. New York: Overlook Press.

Foucault, Michel. 1979. Discipline and Punish. New York: Vintage Books.

Girls Inc. 2006. "The Supergirl Dilemma: Girls Feel the Pressure to be Perfect, Accomplished, Thin, and Accommodating." Press release on its commissioned report, The Supergirl Dilemma: Girls Grapple with the Mounting Pressure of Expectations, I2 October. Accessed 3 June 20I . <http://www.girlsinc.org/news/press-releases/ p2-I-36.html>.

Goldman, Robert, Deborah Heath, and Sharon L. Smith. I99ı. "Commodity Feminism." Critical Studies in Mass Communication 8(3): 333-5I.

Handler, Ruth, with Jacqueline Shannon. 1994. Dream Doll. Stamford, CT: Longmeadow Press.

Heyes, Cressida J. 2007. Self-Transformations: Foucault, Ethics and Normalized Bodies. Oxford: Oxford University Press. 
Hook, Melissa. 1999. "Material Girl." In The Barbie Chronicles: A Living Doll Turns Forty, ed. Yona Zeldis McDonough, I69-74. New York: Simon \& Schuster.

Hymowitz, Kay. 200I. "The Teening of Childhood." Symposium I02(6): I3-2I.

Inness, Sherrie A. I999. "Barbie Gets a Bum Rap: Barbie's Place in the World of Dolls." In The Barbie Chronicles: A Living Doll Turns Forty, ed. Yona Zeldis McDonough, I77-8I. New York: Simon \& Schuster.

Jones, Wendy Singer. 1999. "Barbie's Body Project.” In The Barbie Chronicles: A Living Doll Turns Forty, ed. Yona Zeldis McDonough, 9I-I07. New York: Simon \& Schuster.

Kearney, Mary Celeste. 2009. "Coalescing: The Development of Girls' Studies.” NWSA Journal 2I(I): I-28.

- 2006. Girls Make Media. New York: Routledge.

Kuther, Tara L., and Erin McDonald. 2004. "Early Adolescents' Experiences with, and Views of, Barbie.” Adolescence 39(153): 39-51.

Lamb, Sharon, and Lyn Mikel Brown. 2007. Packaging Girlhood: Rescuing Our Daughters from Marketers' Schemes. New York: St. Martin's Press.

Levin, Diane, and Jean Kilbourne. 2008. So Sexy So Soon: The New Sexualized Childhood and What Parents Can Do to Protect Their Kids. New York: Ballantine Books.

Levinthal, David. 2oIo. Bad Barbie. New York: JMc \& GHB Editions.

I998-99. Barbie Millicent Roberts 1998-1999. Accessed 6 June 20II. <http:// www.davidlevinthal.com/works.html>.

Lord, M. G. 1994. Forever Barbie: The Unauthorized Biography of a Real Doll. New York: William Morrow.

Mitchell, Claudia A., and Jacqueline Reid-Walsh, eds. 2007. Girl Culture: An Encyclopedia. 2 vols. Santa Barbara, CA: Greenwood Publishing.

Morgan, Kathryn Pauly. 1995. "Women and the Knife: Cosmetic Surgery and the Colonization of Women's Bodies." In "Nagging" Questions: Feminist Ethics in Everyday Life, ed. Dana E. Bushnell, 305-34. Lanham, MD: Rowman \& Littlefield.

Naidus, Beverly. 2007. "Profile: Beverly Naidus's Feminist Activist Art Pedagogy: Unleashed and Engaged." NWSA Journal I9(I): I37-55.

Orenstein, Peggy. 2or I. Cinderella Ate My Daughter: Dispatches from the Front Lines of the New Girlie Girl Culture. New York: HarperCollins.

Owens Patton, Tracey. 2006. "Hey Girl, Am I More than My Hair?: African American Women and Their Struggles with Beauty, Body Image, and Hair." NWSA Journal I8(2): 24-5I.

P!nk. 2006. "Stupid Girls.” Music video, directed by Dave Meyers. MTV's Overdrive channel.

Quindlen, Anna. 1999. "Barbie at 35." In The Barbie Chronicles: A Living Doll Turns Forty, ed. Yona Zeldis McDonough, II 7-19. New York: Simon \& Schuster.

Raynor, Sharon. 2009. "My First Black Barbie: Transforming the Image." Cultural Studies $\leftrightarrow$ Critical Methodologies 9(2): I79-85.

Reid-Walsh, Jacqueline, and Claudia Mitchell. 200I. "'Just a Doll'? 'Liberating' Accounts of Barbie-Play." Review of Education, Pedagogy, EJ Cultural Studies 22(2): 175-90.

Reif, Brett. 2003. Fried Barbis [sic]. Accessed 6 June 20I I. <http://www.gibson-reif.com/ reif/work/orObjects/fried_barbi.htm>.

Rodriguez, Nelson M. 1998. "Emptying the Content of Whiteness: Toward an 
Understanding of the Relation between Whiteness and Pedagogy." In White Reign: Deploying Whiteness in America, ed. Joe L. Kincheloe, Shirley R. Steinberg, Nelson M. Rodriguez, and Ronald E. Chennault, 3I-62. New York: St. Martin's Press.

Staurowsky, Ellen J., Mary Jane DeSouza, Gaele Ducher, Noah Gentner, Kathleen E. Miller, Sohaila Shakib, Nancy Theberge, and Nancy I. Williams. 2009. "Her Life Depends on It II: Sport, Physical Activity and the Health and Well-Being of American Girls and Women." East Meadow, NY: Women's Sports Foundation. Accessed 3 June 20II. <http://www.womenssportsfoundation.org/ /media/Files/Research \%2oReports/Her\%2oLife\%2oDepends\%2oOn\%2oIt\%2oII\%2o\%2oCovers \%2oand\%2oInside\% 20 with\%2oDecember.pdf>.

Stern, Susan, producer and director. 1998. Barbie Nation: An Unauthorized Tour. El Rio Productions. Motion picture.

Sweeney, Camille. 2008. "Never Too Young for That First Pedicure." 2008. New York Times, 28 February. Accessed 3 June 201 r. <http://www.nytimes.com/2008/02/28/ fashion/28Skin.html>.

Valenti, Jessica. 2007. Full Frontal Feminism. Berkeley, CA: Seal Press.

Warhol, Andy. 1985. Barbie. Accessed 6 June 20II. <http://www.barbiemedia.com/ ?subcat $=9>$.

Young, Iris Marion. 1990. "Women Recovering Our Clothes.” In Young, Throwing Like a Girl and Other Essays in Feminist Philosophy and Social Theory, 62-74. Bloomington: Indiana University Press.

Ziesler, Andi. 2008. Feminism and Pop Culture. Berkeley, CA: Seal Press. 